\title{
Contrast agent-induced nephrotoxicity: role of oxidative stress and apoptosis through the mitochondrial pathway
}

\author{
J. D. Stewart · J. G. Hengstler $\cdot$ H. M. Bolt
}

Published online: 12 February 2011

(C) Springer-Verlag 2011

Iodinated contrast media may lead to a sudden deterioration in renal function (Laville and Juillard 2010). Approximately $10 \%$ of all hospital-acquired cases of renal failure are caused by contrast agents. However, relatively little is known about the responsible mechanisms in vivo. Therefore, the editors are happy that Carlo Briguori, Cristina Quintavalle, Francesa De Micco and Gerolama Condorelli from Naples and Milan in Italy have contributed a review of the molecular mechanisms of contrast agent-induced nephrotoxicity (Briguori et al. 2010, this issue). Several human and animal studies have given strong evidence that oxidative stress plays an important role in contrast agentinduced acute kidney injury. Furthermore, as caspase 9 and 3 are activated but caspase 8 and 10 are not, apoptosis is therefore induced via the mitochondrial pathway. Since both, reactive oxygen species (Bolt and Hengstler 2010; Nishimura et al. 2010; Cederbaum et al. 2009; Wang et al. 2009a, b; Schumann et al. 2009; Schug et al. 2008; Glahn et al. 2008) and apoptosis (Han and Park 2010; Ogata et al. 2010; Wang et al. 2009a, b; Plöttner et al. 2009; Borza et al. 2008; Lehmann et al. 2010) represent cutting-edge topics of our journal, the current review may be of high interest to our readers.

Moreover, the authors have reviewed 17 clinical studies on prophylaxis of contrast agent-induced nephrotoxicity. As a result, they conclude that oral treatment with the

J. D. Stewart $(\bowtie) \cdot$ J. G. Hengstler · H. M. Bolt

Leibniz Institut für Arbeitsforschung an der TU Dortmund,

Leibniz Research Centre for Working Environment

and Human Factors (IfADo), Ardeystrasse 67,

44139 Dortmund, Germany

e-mail: stewart@ifado.de potent antioxidant $\mathrm{N}$-acetylcysteine appears to be effective in preventing renal failure.

\section{References}

Bolt HM, Hengstler JG (2010) Oxidative stress and hepatic carcinogenesis: new insights and applications. Arch Toxicol 84:87-88

Borza A, Plöttner S, Wolf A, Behm C, Selinski S, Hengstler JG, Roos PH, Bolt HM, Kuhlmann J, Föllmann W (2008) Synergism of aromatic amines and benzo[a]pyrene in induction of Ah receptordependent genes. Arch Toxicol 82:973-980

Briguori C, Quintavalle C, De Micco F, Condorelli G (2010) Nephrotoxicity of contrast media and protective effects of acetylcysteine. Arch Toxicol (this issue)

Cederbaum AI, Lu Y, Wu D (2009) Role of oxidative stress in alcoholinduced liver injury. Arch Toxicol 83:519-548

Glahn F, Schmidt-Heck W, Zellmer S, Guthke R, Wiese J, Golka K, Hergenröder R, Degen GH, Lehmann T, Hermes M, Schormann W, Brulport M, Bauer A, Bedawy E, Gebhardt R, Hengstler JG, Foth H (2008) Cadmium, cobalt and lead cause stress response, cell cycle deregulation and increased steroid as well as xenobiotic metabolism in primary normal human bronchial epithelial cells which is coordinated by at least nine transcription factors. Arch Toxicol 82:513-524

Han YH, Park WH (2010) Proteasome inhibitor MG132 reduces growth of As4.1 juxtaglomerular cells via caspase-independent apoptosis. Arch Toxicol 84:689-698

Laville M, Juillard L (2010) Contrast-induced acute kidney injury: how should at-risk patients be identified and managed? J Nephrol 23:387-398

Lehmann ML, Selinski S, Blaszkewicz M, Orlich M, Ovsiannikov D, Moormann O, Guballa C, Kress A, Truss MC, Gerullis H, Otto T, Barski D, Niegisch G, Albers P, Frees S, Brenner W, Thüroff JW, Angeli-Greaves M, Seidel T, Roth G, Dietrich H, Ebbinghaus R, Prager HM, Bolt HM, Falkenstein M, Zimmermann A, Klein T, Reckwitz T, Roemer HC, Löhlein D, Weistenhöfer W, Schöps W, Beg AE, Aslam M, Bánfi G, Romics I, Ickstadt K, Schwender H, Winterpacht A, Hengstler JG, Golka K (2010) Rs710521[A] on chromosome 3q28 close to TP63 is associated with increased urinary bladder cancer risk. Arch Toxicol 84:967-978 
Nishimura J, Saegusa Y, Dewa Y, Jin M, Kawai M, Kemmochi S, Harada T, Hayashi SM, Shibutani M, Mitsumori K (2010) Antioxidant enzymatically modified isoquercitrin or melatonin supplementation reduces oxidative stress-mediated hepatocellular tumor promotion of oxfendazole in rats. Arch Toxicol 84:143-153

Ogata I, Kawanai T, Hashimoto E, Nishimura Y, Oyama Y, Seo H (2010) Bisabololoxide A, one of the main constituents in German chamomile extract, induces apoptosis in rat thymocytes. Arch Toxicol 84:45-52

Plöttner S, Selinski S, Bolt HM, Degen GH, Hengstler JG, Roos PH, Föllmann W (2009) Distinct subtypes of urinary bladder epithelial cells with inducible and non-inducible cytochrome P450 1A1. Arch Toxicol 83:131-138

Schug M, Heise T, Bauer A, Storm D, Blaszkewicz M, Bedawy E, Brulport M, Geppert B, Hermes M, Föllmann W, Rapp K,
Maccoux L, Schormann W, Appel KE, Oberemm A, GundertRemy U, Hengstler JG (2008) Primary rat hepatocytes as in vitro system for gene expression studies: comparison of sandwich, Matrigel and 2D cultures. Arch Toxicol 82:923-931

Schumann A, Bauer A, Hermes M, Gilbert M, Hengstler JG, Wilhelm C (2009) A rapid and easy to handle thermoluminescence based technique for evaluation of carbon tetrachloride-induced oxidative stress on rat hepatocytes. Arch Toxicol 83:709-720

Wang L, Wang H, Hu M, Cao J, Chen D, Liu Z (2009a) Oxidative stress and apoptotic changes in primary cultures of rat proximal tubular cells exposed to lead. Arch Toxicol 83:417-427

Wang Y, Xu Y, Wang H, Xue P, Li X, Li B, Zheng Q, Sun G (2009b) Arsenic induces mitochondria-dependent apoptosis by reactive oxygen species generation rather than glutathione depletion in Chang human hepatocytes. Arch Toxicol 83:899-908 